\title{
Dissolution and transport of gypsum in gypsiferous soil treated with fuel oil and bentonite
}

\author{
R. M. Shihab ${ }^{1}$ A. N. Al-Ani, ${ }^{2}$ and A. A. Fahad ${ }^{1}$
}

${ }^{1}$ Soil and Water Dept., Agricultural Research Center, P. O. Box 765, Baghdad, Iraq. ${ }^{2}$ Ministry of

Agriculture, P. O. Box 5923 Baghdad, Iraq

\begin{abstract}
Dissolution and transport of gypsum were measured in columns of gypsiferous soil (25\% gypsum). Gypsiferous soil material was treated with fuel oil (FO) and bentonite (Bt) and leached with river water. A model based on convection-dispersion solute transport, the continuity equation, and the first-order kinetic dissolution of gypsum was used to describe the rate of gypsum dissolution in soil in relation with solute transport parameters. Results showed that the application of FO and Bt reduced the solubility of gypsum as indicated by the reduction in dissolution rate coefficient $(\mathrm{K})$. The model described very well the dissolution of gypsum. The reduction in $\mathrm{K}$ was associated with the reduction in mass transfer rate coefficient $(\alpha)$. When the value of $\alpha$ was fixed the value of $K$ varied little, no matter what the variation in both dispersion coefficient (D) and average pore water velocity (v). It is concluded that the value of $\mathrm{K}$ depends mainly on the specific surface area and sorptivity of the soil.
\end{abstract}

Key words: dissolution, gypsiferous soil, gypsum, solute transport, sorptivity,

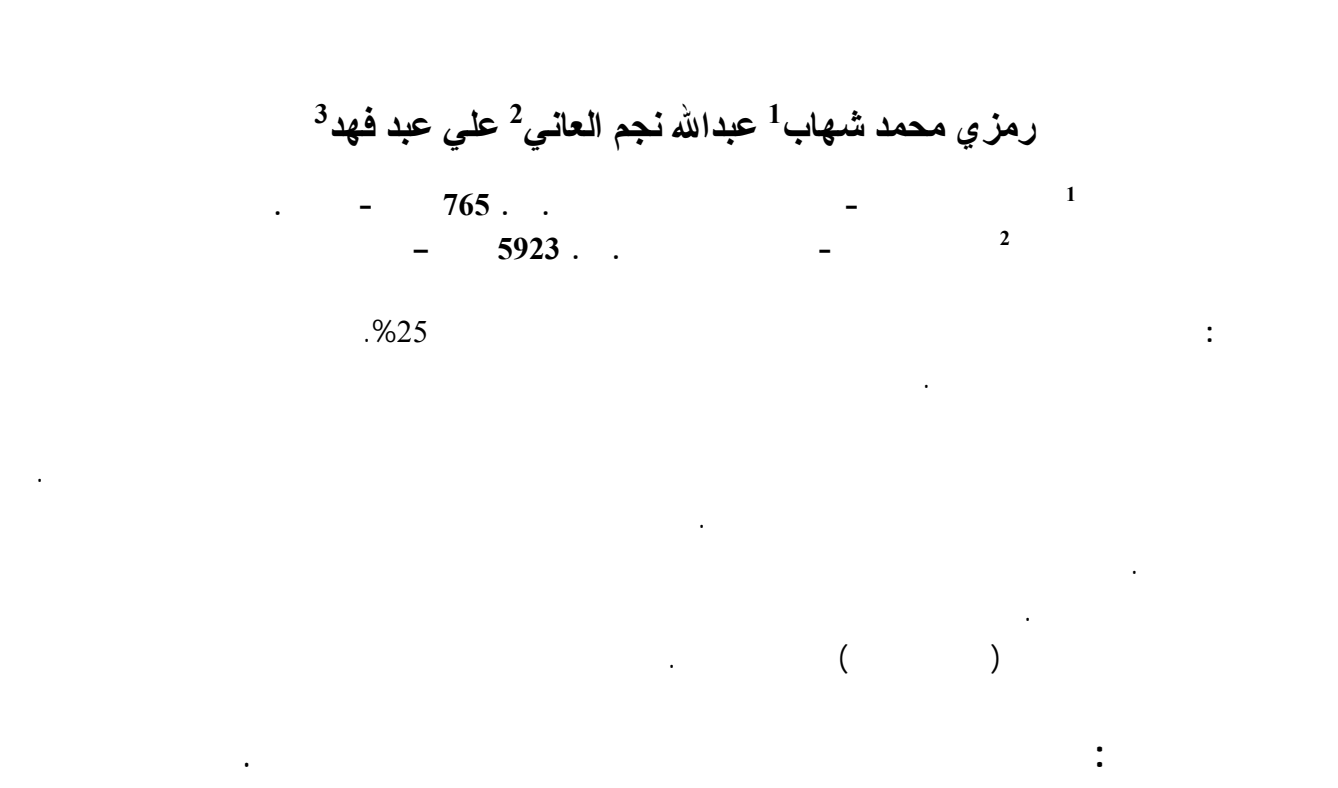

\section{Introduction}

Gypsiferous soils are mainly found in arid and semi-arid regions where precipitation is not enough to leach gypsum from the soil profile. These soils occupy about $20 \%$ of the total area in Iraq, which is equivalent to about $8.7 \%$ of the total area of gypsiferous soils in the world (FAO, 1990). Gypsiferous soil contains, gypsum $\left(\mathrm{CaSO}_{4} \cdot 2 \mathrm{H}_{2} \mathrm{O}\right)$ in an amount that presents some constraints for growing crops.
The relatively moderate solubility of gypsum in water renders such soils susceptible to sink-hole formation and caving. Several investigators have tried to reduce the solubility of gypsum by coating gypsum molecules with less soluble materials. For this purpose, Al-Kaissy and Naji (1985) used barium chloride; Younan (1986) used barium chloride, potassium and ammonium oxalate and ammonium carbonate, whereas Al-Janabi (1990) used 
ammonium phosphate and ammonium carbonate. Petroleum by-products have been successfully used to improve the structure of gypsiferous soils and plant growth (Al-Salih, 1994; Al-Hadithi, 1995). Bentonite was also used to improve productivity of a gypsiferous soil (Al-Kaissy, 1983).To describe the dissolution of gypsum in flowing water, Keisling et al. (1978) developed a model based on the convection-dispersion of solute, the continuity equation and the first-order kinetic dissolution of gypsum. The model requires the estimation of gypsumfragments size, solution flow velocity, dispersion coefficient and mass transfer rate coefficient. Despite their importance in characterizing gypsiferious soils, dissolution and transport of gypsum have received rather limited attention.

Keisling et al. (1978) developed a method based on the analytical solution of Kemper et al. (1975) equation which is written as follows:

$$
\frac{\partial c}{\partial t}=D \frac{\partial^{2} c}{\partial x^{2}}-v \frac{\partial c}{\partial x}+\alpha\left(c_{s}-c\right) \quad \cdots \cdots \cdots \cdots[1]
$$

Where $\mathrm{c}$ is the concentration of solution within volume element; $\mathrm{D}$ is the dispersion coefficient; $\mathrm{t}$ and $\mathrm{x}$ are time and distance variables; $\mathrm{v}$ is the average pore water velocity (i.e. $v=q / \theta$, where $q$ is Darey's flux and $\theta$ is the saturated volumetric water content of soil); $\alpha$ is the first-order mass transfer rate coefficient; and $c_{s}$ is the concentration of saturated solution.

To find an analytical solution of $\mathrm{Eq}[1]$; Keisling et al.(1978) assumed steady state conditions (i.e. $\frac{\partial c}{\partial t}=0$ ) and the following boundary conditions:

$$
\begin{aligned}
& x=0, c=c_{0} \\
& x=\infty, c=c_{s} \\
& c=c_{s}+\left(c_{0}-c_{s}\right) \exp \left\{x\left[\frac{v}{2 D}-\frac{v^{2}+4 D \alpha}{4 D^{2}}\right]^{0.5}\right\}
\end{aligned}
$$

where $\mathrm{c}_{0}$ is the initial concentration of solution and $\mathrm{x}$ is the length of the soil column used in the study.

By comparing their solution with the solution obtained by Kemper et al. (1975); Keisling et al. (1978) obtained the following equation:

$$
K=v\left[\left(\frac{v^{2}+4 D \alpha}{4 D^{2}}\right)^{0.5}-\frac{v}{2 D}\right] \quad \ldots \ldots \ldots \ldots \ldots \ldots \ldots . \quad[4]
$$

where $\mathrm{K}$ is the gypsum dissolution coefficient.

Keisling et al. (1978) related $\alpha$ to the specific surface area (s) to find the following equation:

$$
\alpha=0.0043 s^{1.48}
$$

where 0.0043 and 1.48 are empirical factors.

The present study was therefore conducted to: (1) investigate the influence of fuel oil and bentonite on dissolution and transport of gypsum in soil; (2) evaluate the suitability of Keisling et al. (1978) model to describe the dissolution of gypsum in relation to $\left({ }^{36} \mathrm{Cl}\right)$ solute transport parameters.

\section{Materials and methods}

Soil material containing $25 \%$ gypsum by weight was prepared by mixing the surface $(0-15 \mathrm{~cm})$ layer with the subsurface (below $15 \mathrm{~cm}$ ) layer of a gypsiferous soil from AlDor Research Station, about $150 \mathrm{~km}$. north of Baghdad, Iraq. Some characteristics of the surface and subsurface layers are presented in Table 1.

The prepared mixture was passed through a 2-mm opening sieve. Samples of the mixture were treated with bentonite (70\% montmorillonite) and fuel oil (petroleum by-product) which has a specific gravity of 0.95 and a viscosity of 120 cstocks. The treatments were as follows: $1 \%$ bentonite; $1 \%$ bentonite $+0.5 \%$ fuel oil; and $2 \%$ fuel oil.

Samples of the control (untreated) and the treated materials were packed to a depth of 
$0.30 \mathrm{~m}$ in Perspex tubes $0.50 \mathrm{~m}$ long and 0.12 m. ID following Yaron et al. (1966). The packed columns were wetted from the bottom with saturated gypsum solution to bring the soil to the initial condition with respect to the ionic concentration of the solution phase.

The columns were then leached by maintaining a $2.5 \mathrm{~cm}$ depth of river water on the soil surface. The gypsum concentration was determined in leachate samples collected at different times with the aid of a fraction collector. The leaching process was discontinued when 2.5 pore volumes had passed through each column. ${ }^{36} \mathrm{Cl}$ was used in a separate leaching experiment for estimating D following the method of van Genuchten and Wierenga (1986). The surface area of soil granules was estimated according to Kemper et al. (1975). Granules less than 2-mm in diameter were used to determine the values of bulk density and porosity. The specific surface area of the granules was calculated assuming spherical shape and a real density of $2.4 \mathrm{Mg} / \mathrm{m} 3$. Sorptivity of aggregates was measured according to Al-Ani and Dudas (1988)

Table 1. Some characteristics of gypsiferous soil used in the study

\begin{tabular}{lcc}
\hline & Surface layer & Subsurface layer \\
\hline Texture & Clay loam & + \\
Sand $(\mathrm{g} / \mathrm{kg})$ & 309.8 & + \\
Silt $(\mathrm{g} / \mathrm{kg})$ & 382.4 & + \\
Clay $(\mathrm{g} / \mathrm{kg})$ & 307.8 & + \\
$\mathrm{ECe}(\mathrm{dS} / \mathrm{m})$ & 2.31 & 2.73 \\
$\mathrm{pH}$ & 7.76 & 7.91 \\
$\mathrm{Calcium}$ carbonate $(\mathrm{g} / \mathrm{kg})$ & 336.0 & 173.9 \\
Gypsum $(\mathrm{g} / \mathrm{kg})$ & 20.0 & 675.0 \\
Cation exchange capacity (cmole/kg) & 28.2 & 18.5 \\
Soluble ions (mmol/l) & & \\
Ca & 16.8 & 26.0 \\
$\mathrm{Mg}$ & 3.0 & 2.1 \\
$\mathrm{Na}$ & 2.4 & 1.7 \\
$\mathrm{SO}$ & 103.3 & 20.8 \\
\hline + Data not available due to high gypsum content which inhibits soil dispersion
\end{tabular}

\section{Results and discussion}

Solubility of Gypsum

Fig. 1 shows the concentration of gypsum in leachate of the original soil material (control) and of soil material treated with FO and Bt. It is evident that the solubility of gypsum decreased when FO content increased from 0.5 to $2.0 \%$. Results also indicate that adding $0.5 \%$ of $\mathrm{Bt}$ has reduced to some extent the solubility of gypsum. The solubility was highest in the control (untreated) and decreased in the following order
: Untreated $>1 \% \mathrm{Bt}>1 \% \mathrm{Bt}+0.5 \%$ FO $>2 \%$ FO. According to Glas et al. (1979) solubility of gypsum is controlled by the solubility product of solid-phase gypsum. Solubility product per se is reduced by the application of both FO and Bt. In general, gypsum content in the effluent increased during the first stage of leaching. Then it decreased to a specified value which remained nearly constant with further leaching.

Application of Bt and FO had apparently reduced the specific surface area of the soil 
(Table 2). This may have reduced the surface area in contact with percolating water thus reducing gypsum solubility. Application of $\mathrm{Bt}$ and $\mathrm{FO}$ also modified the structure of the soil and reduced the breakdown of aggregates in

Water. This is due to the fact that FO, which is a hydrophobic material, partially coated the soil aggregates whereas Bt reduced the rate of capillary movement of water into the aggregates (Das and Dakshinamurti, 1975). These effects increased the resistance of aggregates to destruction by water owing to the reduction in the sorptivity of soil aggregates as shown in Table 2 (Al-Ani and Dudas, 1988).

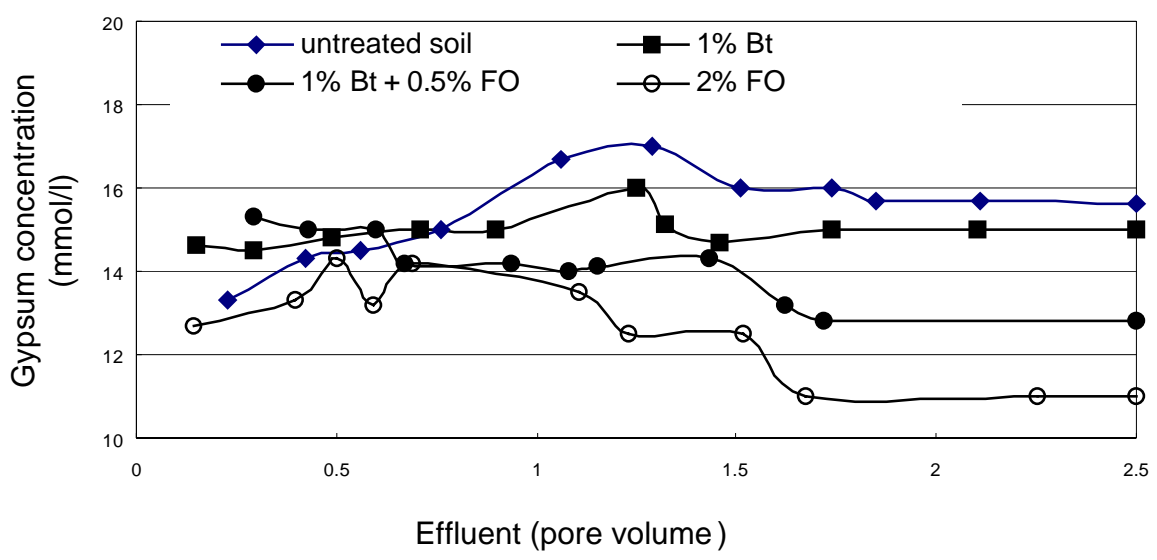

Fig. 1. Gypsum concentration as influenced by pore volumes of river water that has passed through soil columns with different FO and Bt contents.

The amount of gypsum dissolved is related to the time the water stayed within the soil column. For example, Fig 2 indicates that the time needed to pass one pore volume $(1540 \mathrm{ml})$ of water through the soil columns was $40.2,14.2,14.7$ and $9.9 \mathrm{~h}, \quad$ for untreated, $1 \% \mathrm{Bt}$, $1 \% \mathrm{Bt}+0.5 \% \mathrm{FO}$, and $2 \% \mathrm{FO}$, respectively. This difference in time can be attributed to the reduction in flow rate or sorptivity associated with the precipitation of dissolved gypsum at lower layers in the column as indicated by Keren et al. (1980). Sectioning the soil columns at the end of the leaching experiment indicated that gypsum has accumulated in the middle layers of the soil columns. The depth of accumulation ranged between 8 and $16 \mathrm{~cm}$ below the soil surface for the different treatments

Table 2. Characteristics of soil columns used in the leaching studies

\begin{tabular}{lcccc}
\hline Treatment & $\begin{array}{c}\text { Bulk density } \\
(\mathbf{M g} / \mathbf{m 3})\end{array}$ & $\begin{array}{c}\text { Porosity } \\
(\mathbf{\%})\end{array}$ & $\begin{array}{c}\text { Specific } \\
\text { surface area } \\
(\mathbf{c m} 2 / \mathbf{c m})\end{array}$ & $\begin{array}{c}\text { Sorptivity } \\
(\mathbf{c m} / \mathbf{m i n} \mathbf{1 / 2})\end{array}$ \\
\hline Control & 1.30 & 45.8 & 32.5 & 0.411 \\
$1 \% \mathrm{Bt}$ & 1.22 & 49.2 & 30.5 & 0.403 \\
$1 \% \mathrm{Bt}+0.5 \% \mathrm{FO}$ & 1.17 & 51.2 & 29.3 & 0.298 \\
$2 \% \mathrm{FO}$ & 1.12 & 53.3 & 28.0 & 0.178 \\
\hline
\end{tabular}




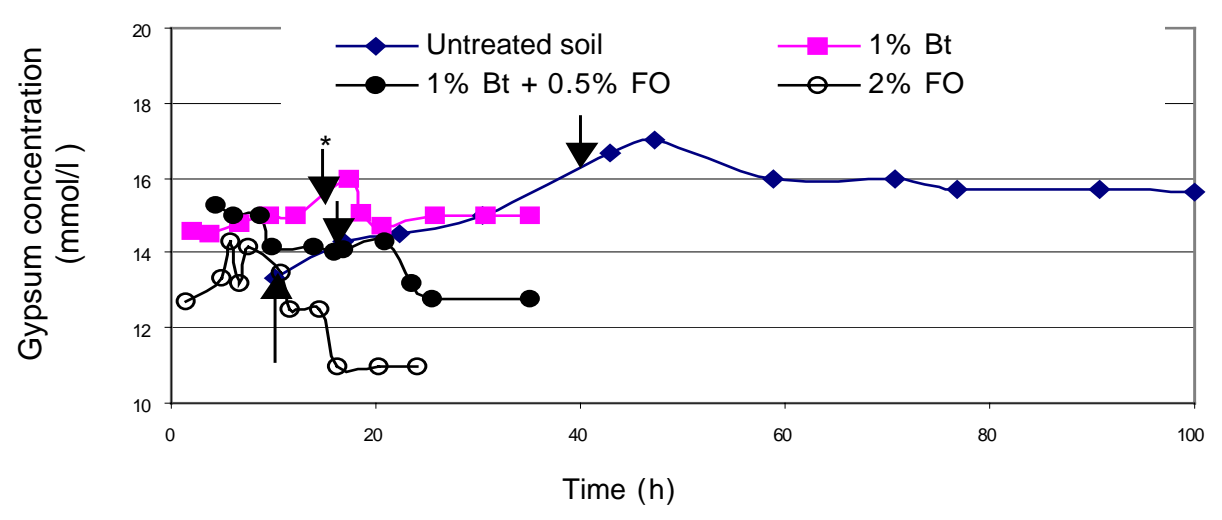

Fig. 2. Gypsum concentration as influenced by time of leaching with river water of soil columns with different FO and Bt contents.

Dissolution and Transport Parameters

The effect of dispersion coefficient (D), velocity flux (v), and mass transfer rate coefficient $(\alpha)$ evaluated by equation [4] on dissolution coefficient $(\mathrm{K})$ of gypsiferous soil is given in Table 3 . In the $\mathrm{Bt}$ and $\mathrm{FO}$ treated columns, the values of $\mathrm{K}$ and $\alpha$ were lower whereas the values of $\mathrm{D}$ and $\mathrm{v}$ were higher, compared to the control. However, the magnitude of changes of these four parameters was different. While D and v increased sharply with the application of $\mathrm{Bt}$ and FO, K and $\alpha$ decreased little. The values of $\mathrm{K}$ were close to those of $\alpha$ for both control and treated soil. When the value of $\alpha$ is fixed, the value of $\mathrm{K}$ varies little with variation in the values of $\mathrm{D}$ and $\mathrm{v}$. This indicates that the value of $\mathrm{K}$ depends mainly on the value of $\alpha$. These results prove that dissolution is a surface phenomenon and the value of $\mathrm{K}$ depends mainly on the specific surface area as well as on the sorptivity of soil granules (Table 2).

The results in Table 3 are in agreement with the results of Keisling et al. (1978) which indicate that solute transport depends on the convection-dispersion equation in addition to the first order kinetic dissolution of gypsum. However, the present work differs from that of Kemper et al. (1975) and Keisling et al. (1978) who showed that the value of $\mathrm{K}$ depends not only on $\alpha$, but also on $\mathrm{D}$ and $\mathrm{v}$.

Table 3. Values of K calculated by Eq. [4] at different values of $D, v$, and $\alpha$, and calculated values of Reynold's number.

\begin{tabular}{cccccc}
\hline Treatment & $\begin{array}{c}\mathbf{D} \\
\left(\mathbf{c m}^{\mathbf{2}} / \mathbf{h}\right)\end{array}$ & $\begin{array}{c}\mathbf{v} \\
(\mathbf{c m} / \mathbf{h})\end{array}$ & $\begin{array}{c}\boldsymbol{\alpha} \\
\left(\mathbf{h}^{-\mathbf{1}}\right)\end{array}$ & $\begin{array}{c}\mathbf{K} \\
\left(\mathbf{h}^{-\mathbf{1}}\right)\end{array}$ & $\begin{array}{c}\text { Reynold's } \\
\text { No. }\end{array}$ \\
\hline Untreated soil & 0.02 & 0.54 & 0.74 & 0.71 & $1.0 \times 10^{-3}$ \\
$1 \%$ Bt & 0.24 & 1.62 & 0.68 & 0.64 & $2.5 \times 10^{-3}$ \\
$1 \%$ Bt+0.5 \%FO & 0.30 & 1.68 & 0.64 & 0.60 & $2.7 \times 10^{-3}$ \\
$2 \%$ FO & 0.60 & 2.34 & 0.60 & 0.56 & $3.7 \times 10^{-3}$ \\
\hline
\end{tabular}


Keisling et al. (1978) used a constant value of $\mathrm{D}$, which is equal to $\left(5.4 \times 10^{4} \mathrm{~cm}^{2} / \mathrm{h}\right)$, to check the validity of the derivation of Eq. 4 . This value for $\mathrm{D}$ seems to be very large, even for non-laminar flow conditions. The value of $\mathrm{D}$ in the present study increased from 0.02 to $0.60 \mathrm{~cm}^{2} / \mathrm{h}$ with the increase in the value of $\mathrm{v}$ from 0.54 to $2.34 \mathrm{~cm} / \mathrm{h}$ (Table 3). These values indicate that the mixing process, dispersion and average pore water velocity all are involved in the leaching processes (White, 1985; Campbell, 1985). Therefore, assuming a constant value for D for different flow velocities can introduce serious errors in the calculation of $\mathrm{K}$.

A possible explanation of the independence of $\mathrm{K}$ on $\mathrm{V}$ and $\mathrm{D}$ in the present study is the laminar flow of water through the soil (Reynold's No. ranged from $1 \times 10^{-3}$ $\left.3.7 \times 10^{-3}\right)$. Turbulent flow along granule surfaces may have contributed to the higher values of dissolution coefficient in the study of Keisling et al. (1978). This increase in the dissolution coefficient is partially due to: (i) the rapid leaching of $\mathrm{Ca}$ and $\mathrm{SO}_{4}$ ions when the solution is moving faster, as in the case of the work of Keisling et al. (1978) and (ii) the effect of turbulent eddy currents at higher flow rates (Kemper et al., 1975).

Both the gypsum dissolution rate $(\mathrm{K})$ as shown in Table 3 and gypsum solubility as indicated in Figures 1 and 2 decreased with the application of FO and Bt. The concentration of gypsum in the leachate decreased with $\mathrm{FO}$ and $\mathrm{Bt}$ application owing to the coating of the granules by $\mathrm{FO}$ and $\mathrm{Bt}$, and to the reduction in both specific surface area and sorptivity. Reduction of sorpitvity reduces the breakdown of aggregates (AlAni and Dudas, 1988) caused by reduction in pressure build up within the aggregates (Stroosnyder and Koorevaar, 1972), leading to less breakdown of aggregates and less exposure of surfaces to water which reduces the solubility of gypsum. It can be concluded that Eq.4 can be used to describe the dissolution of gypsum in gypsiferous soils.

\section{Acknowledgment}

The authors would like to thank Mr. T. L. Rasheed for his assistance in the laboratory analysis.

\section{References}

Al-Ani, A. N. and M. Dudas 1988. Influence of calcium carbonate on mean weight diameter of soil. Soil and Tillage Research. 11: 19-27.

Al-Hadithi, S. A. 1995. Effect of fuel oil and biotreated oil on soil properties and plant growth. M.Sc. Thesis, College of Agriculture, University of Baghdad, Baghdad, Iraq. (In Arabic).

Al-Janabi, A. S. 1990. Using of Ammonium Phosphate and carbonate as gypsiferous soil conditioners and their effect on growth and productivity of corn. Ph.D. Thesis, College of Agriculture, University of Baghdad, Baghdad, Iraq. (In Arabic).

Al-Kaissy, A. A. 1983. Effect of bentonite application on some properties of Al-Dor gypsiferous soil and plant growth. M.Sc. Thesis, College of Agriculture, University of Baghdad, Baghdad, Iraq. (In Arabic).

Al-Kaissy, A. A., and T. Naji. 1985. Influence of barium chloride addition on plant growth and some properties of gypsiferous soil. Agri. Water Resources Res. 4(3): 107-119.

Al-Salih, R. A. 1994. Effect of fuel oil level and its date of application on some soil properties and corn growth. M.Sc. Thesis, College of Agriculture, University of Baghdad, Iraq (In Arabic).

Campbell, G. S. 1985. Soil Physics With Basic. Transport Models for Soil Plant 
Systems. Developments in Soil Science 14, Elsevier-Amsterdam, Holland.

Das, D.K., and C. Dakshinamurti. 1975. Bentonite as soil conditioner. In W. C. Moldenhauer et al. (eds) Soil Conditioners SSSA, Special Pub. No. 7:65-76.Soil Sci. Soc. Amer.

FAO, 1990. Management of gypsiferous Soil, Bull. No. 62, Rome, Italy.

Glas, T. K., A. Klute, and D. B. McWhorte. 1979. Dissolution and transport of gypsum in soils: II. Experimental. Soil Sci. Soc. Am. J. 43:268- 273.

Keisling T.C., P.S. Rao, and R.E. Jessup. 1978. Pertinent criteria for describing the dissolution of gypsum beds in flowing water. Soil Sci. Soc. Am. J. 42:234-236.

Kemper, W. D., Olsen, and C.J. DeMooy. 1975. Dissolution rate of gypsum in flowing water. Soil Sci. Soc. Am. J. $39: 458$

Keren, R., J. F. Kreit, and I. Shainberg. 1980. Influence of size of gypsum particles on the hydraulic conductivity of soils. soil. Sci. 130:113-117.
Stroosnyder, L. and P. Koorevaar, 1972. Air pressure within soil aggregates during quick wetting and subsequent explosion. Belg. J. Agric. Sci. 37 :1095-1106.

van Genuchten, M. T., and P. J. Wierenga, 1986. Solute dispersion coefficients and retardation factors. In A. Klute et al. (eds) Methods of Soil Analysis, Part 1. Agron. 9:1025-1054. 2nd . Edition ASA, SSSA. Inc. Madison WI. USA.

White, R. E. 1985. The influence of macropores on the transport of dissolved and suspended matter though soil. advances in soil science. 3:95-120 .

Yaron, B., E. Bresler, and J. Shalhevet. 1966. A method for uniform packing of soil columns. Soil Sci. 101:205-209.

Younan, T. F. 1986. Effect of Potassium oxalate, ammonium carbonate and oxalate, and barium chloride addition on solubility of gypsum in soil. M.Sc. Thesis, College of Agriculture, University of Baghdad, Baghdad, Iraq. (In Arabic). 